\title{
WITRYNA INTERNETOWA JAKO MATERIAŁ ARCHIWALNY
}

\author{
Słowa kluczowe \\ archiwizacja Internetu; wartościowanie zasobów cyfrowych; cyfryzacja; zasoby in- \\ ternetowe
}

\section{Keywords}

Internet archiving; evaluating digital holdings; digitization; Internet content

\section{Streszczenie}

Artykuł podejmuje tematykę archiwizacji Internetu oraz wartościowania witryn internetowych. Rozpoczyna się od zdefiniowania i ustalenia struktury witryny internetowej, w skład której wchodzą strony internetowe i dokumenty HTML. W dalszej części artykułu autor podjął próbę stworzenia podziału witryn internetowych ze względu na ich charakter. Następnie przy wykorzystaniu metod archiwistyki przeprowadził rozważania nad wartością źródłową witryn internetowych. Ostatnią część artykułu stanowi studium przypadku, w którym analizie poddana została witryna internetowa I Liceum Ogólnokształcącego im. Mikołaja Kopernika w Toruniu.

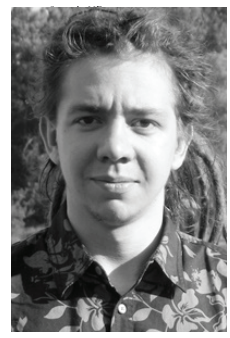

Bartłomiej Konopa, licencjat archiwistyki i zarządzania dokumentacją w Uniwersytecie Mikołaja Kopernika w Toruniu. Obecnie student II r. studiów magisterskich w UMK. Jego zainteresowania naukowe obejmują historię Torunia (zwłaszcza dzieje kultury) oraz miast Prus Krzyżackich, także teorię i metodykę archiwalną w odniesieniu do Internetu. Pasjonuje się muzyką, podróżami, beletrystyką fantastyczną i historyczną oraz filozofią. Tematem pracy licencjackiej napisanej pod kierunkiem prof. Andrzeja Radzimińskiego były Przywileje lokacyjne miast w Prusach zakonu krzyżackiego wXIII-XVw. E-mail: bartlomiejkonopa@gmail.com. 
] nternet i jego masowe rozpowszechnienie są jednym z ważniejszych, jeLśli nie najważniejszym z elementów rozwoju technologii informatycznych XXI w. Znalazł on szereg zastosowań w życiu współczesnego człowieka, wykorzystywany jest zarówno jako narzędzie pracy, źródło informacji oraz rozrywki, jak i medium komunikacji międzyludzkiej. Ciągłe rozrastanie się Internetu wydaje się niczym nieograniczone i odkrywa coraz to nowe jego zastosowania, jak np.: chmury internetowe, służące przechowywaniu danych lub dostępowi do aplikacji, lub też niezwykle popularne w ostatnich latach serwisy społecznościowe ${ }^{1}$.

Jednakże przedmiotem tego artykułu jest strona, a raczej witryna lub też serwis, internetowy, czyli w języku angielskim website, i potraktowanie jej jako dokumentacji, a w przyszłość być może także jako materiału archiwalnego. Niniejszy artykuł nie ma celu odpowiedzi na pytania o metodykę archiwizacji witryn internetowych lub też o kwestie prawne z tym związane. Postawionym tu zadaniem jest podjęcie rozważań teoretycznych, postawienie i zasygnalizowaniu pytań, które mogą być pozostawione bez odpowiedzi. Witryna internetowa jest to całość składająca się z jednej lub wielu połączonych ze sobą stron internetowych, przeważnie zamieszczona na jednej domenie internetowej ${ }^{2}$ udostępnianej przez Internet lub sieci lokalnej, do której dotrzeć można za pomocą adresu URL. Poza elementami statycznymi może być ona wzbogacona o dodatkowe funkcje i możliwości takie jak logowanie się, wysyłanie wiadomości, aplikacje lub formularze dokumentów. Wszystkie publicznie dostępne witryny internetowe tworzą World Wide Web, czyli w skrócie $\mathrm{WWW}^{3}$.

Podstawowym elementem witryny jest strona internetowa, po angielsku web page $e^{4}$ Strona internetowa to stworzony najczęściej za pomocą języka HTML dokument, udostępniany za pomocą WWW lub sieci LAN i wyświetlany przy użyciu przeglądarki internetowej jako wynik przetworzenia kodu zawartego w pliku HTML. Składać się ona może z tekstu, obrazów i grafik, elementów multimedialnych, paska nawigacyjnego, bocznego menu, hiperłączy

\footnotetext{
1 Języki programowania komputerów, red. L. Pawłowski, Lublin 2010, s. 131.

${ }^{2}$ Website, http://www.oxforddictionaries.com/definition/english/website (dostęp: 10 VI 2015 r.).

3 M. Sokół, ABC języka HTML i XHTML, Gliwice 2012, s. 23-26.

${ }^{4}$ Web page, http://www.oxforddictionaries.com/definition/english/web-page (dostęp: 10 VI 2015 r.).
} 
itp. Strony internetowe można podzielić na statyczne i dynamiczne. Pierwsze, co wywnioskować można z ich nazwy, zawsze są wyświetlane tak samo według ich kodu, natomiast strony dynamiczne zmieniają się od potrzeb chwili. Jako przykład może posłużyć tu wynik wyszukiwania w bazie SEZAM na stronie Naczelnej Dyrekcji Archiwów Państwowych (NDAP), który zmienia się w zależności od zapytania skierowanego przez użytkownika ${ }^{5}$.

Polscy archiwiści nie pokusili się jeszcze o stworzenie definicji witryny ani strony internetowej ze strony polskiej archiwistyki. Jednak nie wydaje się, aby miała ona różnić się od tych przytoczonych. Niezbędne będzie przypisanie witryny internetowej do konkretnego rodzaju dokumentacji lub wykreowanie dla niej osobnego rodzaju, obejmującego te zasoby internetowe. Przy tej okazji konieczne wydaje się dokonanie, choćby ogólnego, ich podziału. Witryny internetowe swoją zawartością obejmują szerokie spektrum treści, niezwykle bogate, ale jednocześnie trudne do scharakteryzowania. Można wyróżnić kilka podstawowych grup, dla których można wskazać odpowiedniki w formie analogowej. Do pierwszej z nich zaliczać się będą m.in. witryny należące do instytucji administracji publicznej, przedsiębiorstw, firm, banków itp., pełniących głównie funkcje informacyjne oraz realizujących funkcje reklamowe lub promocyjne. Te można by przypisać do materiałów ulotnych, gdyż noszą one znamiona interaktywnego folderu lub broszury, lub też, ze względu na specyfikę, utworzyć nową grupę, ewentualnie podgrupę w ramach wspomnianych materiałów ulotnych ${ }^{6}$. Następną grupę stanowić będą wszelkiego rodzaju serwisy i portale hobbystyczne lub naukowe, prowadzone raczej przez prywatne osoby, które można by traktować jako publikacje. Kolejna grupa to wszelkiego rodzaju serwisy informacyjne, które zdają się przypominać publikacje prasowe ${ }^{7}$. Ponadto można wskazać blogi i podobne im witryny, które są cyfrowym odpowiednikiem pamiętnikarstwa, oraz wirtualne muzea lub galerie sztuki, które odpowiadają analogowym przewodnikom lub katalogom wystaw. Inną grupę stanowią media społecznościowe, które w przeciwieństwie do pozostałych, ze względu na specyfikę trudno jest określić i przyrównać do konkretnego rodzaju dokumentacji istniejącej w świecie realnym. Biorąc pod uwagę niejednolitość i szybki rozwój Internetu, możliwe jest wzajemne przenikanie się

5 Języki programowania, s. 134-135.

${ }^{6}$ R. Degen, Dokumentacja i jej podziat, [w:] Współczesna dokumentacja urzędowa, red. H. Robótka, Toruń 2011, s. 26-27.

${ }^{7}$ K. Ślaska, A. Wasilewska, Archiwizacja Internetu - sytuacja w polskim prawie z punktu widzenie bibliotekarzy, „Biuletyn EBIB”, 2012, nr 1, s. 3-6, http://www.ebib. pl/images/stories/numery/128/128_slaska.pdf (dostęp: 11 VI 2015 r.). 
wymienionych grup ${ }^{8}$ W niniejszym artykule wzięta pod uwagę będzie głównie pierwsza $\mathrm{z}$ nich, $\mathrm{z}$ naciskiem na witryny jednostek organizacyjnych znajdujących się pod nadzorem archiwalnym.

Według obiegowej opinii to, co zostanie rzucone w otchłań Internetu, już $\mathrm{w}$ niej pozostaje. Nie jest to jednak do końca prawdziwe stwierdzenie. Internet i zawarte w nim informacje ulegają nieustanym zmianom, modyfikacjom i aktualizacjom. Mogą również zostać usunięte przez właściciela witryny lub też przez administratora serwera, na którym jest ona umieszczona, np.: gdy nie zostanie uiszczona opłata za domenę lub przez dłuższy okres jest ona nieaktywna. Dana informacja więc, o ile nie zostanie w jakiś sposób zabezpieczona, może zniknąć. W czasach, gdy witryny internetowe są coraz częściej cytowane oraz gdy cieszą się zainteresowaniem i odgrywają istotną rolę w społeczeństwie informacyjnym, podejmowanie działań mających na celu ich zachowanie okazuje się niezwykle korzystne ${ }^{9}$.

Jest to jednak ogólny argument przemawiający za potrzebą archiwizowania Internetu. Jednak czy witrynę internetową, po włączeniu jej w obręb dokumentacji wytwarzanej przez daną jednostkę, można potraktować jako materiał archiwalny? Na pewno ważne jest tu kryterium unikatowości. Każda instytucja posiada i prowadzi przeważnie jedną witrynę internetową, która zawiera informacje o niej, bieżące wiadomości, dane kontaktowe itp. Dodatkowe zakładane są wyłącznie w razie potrzebny, np.: dla dużych projektów prowadzonych przez ministerstwa. Mamy tu do czynienia przede wszystkim $\mathrm{z}$ unikatowością formy ${ }^{10}$.

Za włączeniem witryn internetowych w krąg materiałów archiwalnych opowiada się ich popularność i to, że są ważne dla użytkowników. W dobie coraz większej powszechności Internetu zaczął on służyć do załatwiania potrzeb jego użytkowników oraz poszukiwania informacji. Takie funkcje pełnią witryny internetowe jednostek organizacyjnych. To właśnie od nich użytkownik najczęściej rozpoczyna zdobywanie informacji na temat tej konkretnej jednostki, o sposobach załatwiania spraw, wymaganych dokumentach czy bieżącej działalności tejże jednostki, szuka wzorów formularzy, a także komunikuje się z nią. W ten sposób taka witryna staje się „furtką do systemu informacji

8 S. M. Schafer, HTML, XHTML i CSS, Gliwice 2011, s. 23-24.

9 L. Derfet-Wolf, Archiwizacja Internetu - wprowadzenie i przegląd wybranych inicjatyw, „Biuletyn EBIB”, 2012, nr 1, s. 1-2, http://www.ebib.pl/images/stories/numery/128/128_derfert.pdf (dostęp: 11 VI 2015 r.).

${ }^{10}$ H. Robótka, B. Ryszewski, A. Tomczak, Archiwistyka, Warszawa 1989, s. 41. 
urzędowej”. Oczywiście użytkownik może uzyskać to, co go interesujące, odwiedzając siedzibę jednostki, jednak zdecydowanie chętniej i częściej skorzysta on z Internetu, co wskazuje na ważną rolę serwisów internetowych ${ }^{11}$.

Argumentem przeciwko archiwizacji witryny internetowej może być kryterium niepowtarzalności informacji. Często zdarza się, że informacja zawarta na witrynie internetowej znajduje się również w innej dokumentacji. Aktualności na niej zawartych można by szukać w raportach i sprawozdaniach, informacji na temat funkcjonowania jednostki w wszelkiego rodzaju normatywach, natomiast sposobów załatwiania spraw w informatorach lub przepisach prawnych. Zatem archiwizowanie witryn internetowych powodowałoby dublowanie informacji ${ }^{12}$.

Do traktowania serwisów internetowych jako materiałów archiwalnych zniechęca również ich niekompletność, brak konsekwencji w prowadzeniu i brak regularnych aktualizacji. Witryny internetowe są często prowadzone niedbale i nie zawsze poświęcana jest im uwaga adekwatna do ich roli. Zdarza się, iż wchodząc w zakładkę, pojawia się komunikat "Strona w budowie” bądź jest ona całkowicie pusta albo też nie istnieje. Natrafić można również na lakoniczną lub nieaktualną informację. W konsekwencji doprowadziłoby to do przechowywania informacji wadliwej lub niepełnej.

Prowadzone na całym świecie projekty archiwizowania Internetu można przeciwstawić polskim inicjatywom tego rodzaju. Archiwum Internetu, Internet Archive, przeprowadza już archiwizację całego Internetu (oczywiście nie jest to archiwizacja w stu procentach kompletna), a więc kolejne podobne programy mogą prowadzić do powielania się przechowywanych przez nie zasobów. Jednak polskie narzędzie bądź też projekt wykorzystujący technologie Internet Archive, Wayback Machine, dobrze spopularyzowany i przeprowadzony, mógłby w większym stopniu dotrzeć do polskich użytkowników Internetu ${ }^{13}$.

Teraz należy przejść do przedstawienia jak najszerzej i obiektywniej wymienionych kwestii teoretycznych na przykładzie, za który posłuży witryna internetowa I Liceum Ogólnokształcącego im. Mikołaja Kopernika w Toruniu $^{14}$. Jest to jedna z dwóch toruńskich szkół objętych nadzorem archiwalnym. Drugą jest Gimnazjum i Liceum Akademickie, które jest jednak związane or-

11 S. M. Schafer, dz. cyt., s. 24-27.

12 H. Robótka, B. Ryszewski, A. Tomczak, dz. cyt., s. 40.

13 About the Internet Archive, https://archive.org/about/ (dostęp: 11 VI 2015 r.).

14 Witryna internetowa I Liceum Ogólnokształcącego im. Mikołaja Kopernika w Toruniu, http://www.1lo.torun.pl/1lo/ (dostęp: 11 VI 2015 r.). 
ganizacyjnie z toruńskim uniwersytetem i tu zależności pomiędzy Archiwum Państwowym w Toruniu a szkołą są odmienne. Dlatego w celu przeprowadzenia badania wybrano I LO w Toruniu.

Wśród materiałów archiwalnych, które są przekazywane do archiwum, znajdują się protokoły posiedzeń Rady Pedagogicznej oraz kroniki szkolne, które świetnie odzwierciedlają życie szkoły.

Oczywiste jest, iż jest to jedyna witryna internetowa związana z I LO w Toruniu. Szkoła posiada również profile na portalach społecznościowych: Facebooku, Instagramie, YouTubie oraz Twitterze, są to jednak elementy niepowiązane bezpośrednio z samą witryną, więc znalazły się poza zainteresowaniem autora. Odnośniki do nich znaleźć można na stronie głównej I LO w Toruniu wraz z linkami do dziennika elektronicznego, systemu MOODLE oraz planu lekcji. Poza nimi znajdują się tam dane adresowe, bieżące informacje oraz pasek zakładek. Wśród nich znajdziemy zakładki: Strona główna, O szkole, Spoteczność, Nauka, Poza lekcjami, Rekrutacja, Niezbędnik.

Wewnątrz nich możemy znaleźć bieżące informacje o życiu szkoły, sukcesach, wydarzeniach sportowych czy o historii placówki i jej funkcjonowaniu. Duża cześć ze znajdujących się tam informacji znajdzie swoje odbicie w statucie szkoły, regulaminach oraz protokołach posiedzeń Rady Pedagogicznej. W tych ostatnich znaleźć można najwięcej informacji, zwłaszcza w załączanych do nich sprawozdaniach z nadzoru pedagogicznego dyrektora, w których jest mowa o wydarzeniach, jakie miały miejsce w szkole. Przyłączane są również sprawozdania i protokoły np.: z konkursów, wycieczek i obozów oraz zawodów sportowych. Ponadto obecna dyrektor szkoły gromadzi na własny użytek dokumentację obrazującą życie szkoły. Dodatkowym źródłem są kroniki prowadzone do 2007 r. oraz publikacje wydawane przy okazji zjazdów absolwentów szkoły. Dalej, w zakładce Rekrutacja, znajdują się informacje dotyczące naboru do szkoły, jego zasadach i bieżącym jego etapie oraz potrzebnych dokumentach. Zakładka jest pożyteczna dla kandydatów, bo możliwe, że część z nich to tutaj zaczęła poszukiwania dotyczące przebiegu rekrutacji oraz informacji o ofercie szkoły.

Na witrynie I LO w Toruniu znajdują się niestety „puste strony”, m.in. w zakładce Życie szkoły > Galeria, Społeczność > Kadra > Byli nauczyciele lub Społeczność >In Memoriam> prof. Jacek Bachanek, ponadto pewne zakładki podają nam tylko lakoniczne informacje, które zapewne w szerszym świetle można odnaleźć w tradycyjnej dokumentacji, np.: zakładki dotyczące szkolnego radiowęzła oraz kół zainteresowań. 
Witryna internetowa I LO w Toruniu jest w obecnej chwili niedopracowana, a przynajmniej takie sprawia wrażenie. Wynika to z licznych braków i pustych stron, które stanowią jej część. Same informacje zawarte na witrynie stanowią w większości powielenie informacji, które odnaleźć można w innej dokumentacji tejże instytucji. Wobec powyższego nie wydaje się ona spełniać kryteriów stawianych materiałom archiwalnym. Jednakże wśród dokumentacji przekazywanej do Archiwum Państwowego w Toruniu znajdują się m.in. kroniki szkolne. One również w dużej mierze stanowią powtórzenie informacji zawartych $\mathrm{w}$ dokumentacji oficjalnej. Posiadają one jednak te zalety, iż prowadzone są przez uczniów i nauczycieli oraz dokumentują życie szkoły w sposób bardziej swobodny. Te same zalety posiada omawiana witryna I LO w Toruniu, co skłania do jej zachowania.

Próba potraktowania witryn internetowych jako dokumentacji oraz możliwych materiałów archiwalnych niesie za sobą liczne pytania i problemy. Pierwszym jest już samo ich zdefiniowanie pod kątem właśnie dokumentacji. Kolejnymi są próba usystematyzowania i przypisania do konkretnego rodzaju dokumentacji. Zaproponowany model jest bardzo ogólny i na pewno niewystarczający do opisania tak złożonego zjawiska. Dalej pojawiają się pytania o celowość i sens przechowywania witryn internetowych, czy przechowywać wszystko, czy tylko wybraną część i kto ewentualnie miałby się podjąć tego zadania. W dalszej przyszłości mogą pojawić się kwestie metodyczne oraz prawne, również te związane z udostępnianiem tego zasobu. Opracowane metody działania powinny być jak najbardziej szczegółowe i jak najdokładniej przewidywać rozwój Internetu. Sprawy techniczne posiadają w tym zagadnieniu znaczenie drugorzędne, gdyż możliwe jest opracowanie odpowiednich narzędzi i przygotowanie niezbędnej przestrzeni dyskowej.

\section{Źródła}

Witryna internetowa I Liceum Ogólnokształcącego im. Mikołaja Kopernika w Toruniu, http://www.1lo.torun.pl/1lo/ (dostęp: 11 VI 2015 r.).

\section{- Literatura}

About the Internet Archive, https://archive.org/about/ (dostęp: 11 VI 2015 r.).

Degen R., Dokumentacja i jej podziat, [w:] Współczesna dokumentacja urzędowa, red. H. Robótka, Toruń 2011. 
Derfet-Wolf L., Archiwizacja Internetu - wprowadzenie i przegląd wybranych inicjatyw, „Biuletyn EBIB”, 2012, nr 1, http://www.ebib.pl/images/stories/numery/128/128_ derfert.pdf (dostęp: 11 VI 2015 r.).

Języki programowania komputerów, red. L. Pawłowski, Lublin 2010.

Robótka H., Ryszewski B., Tomczak A., Archiwistyka, Warszawa 1989.

Schafer S. M., HTML, XHTML i CSS. Biblia, Gliwice 2011.

Sokół M., ABC języka HTML i XHTML, Gliwice 2012.

Ślaska K., Wasilewska A., Archiwizacja Internetu - sytuacja $w$ polskim prawie z punktu widzenie bibliotekarzy, „Biuletyn EBIB”, 2012, nr 1, http://www.ebib.pl/images/ stories/numery/128/128_slaska.pdf (dostęp: 11 VI 2015 r.).

Web page, http://www.oxforddictionaries.com/definition/english/web-page (dostęp: 10 VI 2015 r.).

Website, http://www.oxforddictionaries.com/definition/english/website (dostęp: $10 \mathrm{VI}$ 2015 r.).

\section{Summary}

A website as an archival material

The article touches the subject of archiving the Web and evaluating websites. It starts with defining and presenting a structure of a website, comprising of web pages and HTML documents. Further the author attempts to divide websites according to their character. Then, using methods of archival science, the author considered source value of websites. The last part of the article is a case study analysis of the website of the Nicolaus Copernicus High School No. 1 in Torun. 